\title{
Nilai Religius dalam Buku Teks Bahasa Indonesia SMP Kurikulum 2013
}

\author{
Religious Values in Indonesian Language \\ Textbooks SMP Curriculum 2013
}

Nur Indah Sholikhati

Desy Rufaidah

Universitas Sarjanawiyata Tamansiswa, Kota Yogyakarta

nur.indah@ustjogja.ac.id

Riwayat Artikel: Dikirim 27 November 2019; Diterima 12 Juni 2020; Diterbitkan 30 Juni 2020

\begin{abstract}
ABSTRAK
Buku teks merupakan salah satu komponen penting dalam proses pembelajaran. Diharapkan dalam buku teks Bahasa Indonesia tidak hanya terdapat ilmu bahasa dan sastra, tetapi terdapat pula penanaman nilainilai pendidikan karakter. Penelitian ini bertujuan mendeskripsikan penanaman pendidikan karakter religuis dalam buku teks Bahasa Indonesia SMP Kurikulum 2013. Penelitian yang dilakukan merupakan penelitian deskriptif kualitatif. Data pada penelitian ini berupa frasa, kata, klausa, kalimat, paragraf, dan wacana yang memuat konten-konten tentang penanaman pendidikan karakter dalam buku teks Bahasa Indonesia SMP Kurikulum 2013. Dalam penelitian ini, data diperoleh dari buku teks Bahasa Indonesia Kelas VII, VIII, dan IX Kurikulum 2013. Pada penelitian ini instrumen penelitian merupakan peneliti yang dibekali teori mengenai pendidikan karakter. Selain itu, peneliti dilengkapi dengan instrumen berupa kartu data yang memuat pendidikan karakter religius. Instrumen tersebut divalidasi dengan validasi konten oleh pakar (expert judgement) yang dilakukan oleh ahli pengajaran bahasa. Keabsahan data dilakukan dengan teknik pemeriksaan teman sejawat melalui diskusi atau Focus Group Discusion (FGD). Analisis data dalam penelitian ini menggunakan model analisis interaktif.
\end{abstract}

Kata kunci: pendidikan karakter, religius, buku teks.

\section{ABSTRACT}

Textbooks are one important component in the learning process. It is hoped that Indonesian textbooks will not only have linguistics and literature, but there will also be the inculcation of the values of character education. This study aims to describe the cultivation of religious character education in Indonesian Language textbooks at SMP Curriculum 2013. The research conducted was a descriptive qualitative study. The data in this study are in the 
form of phrases, words, clauses, sentences, paragraphs and discourses that contain content about inculcation of character education in Indonesian textbooks for SMP Curriculum 2013. In this study, the data were obtained from Indonesian textbooks Class VII, VIII, and IX Curriculum 2013. In this study, the research instrument is a researcher who is equipped with theories about character education. In addition, researchers are equipped with instruments in the form of data cards containing religious character education. The instrument was validated by content validation by experts (expert judgment) conducted by language teaching experts. The validity of the data is done by peer examination techniques through discussion or Focus Group Discussion (FGD). Data analysis in this study uses an interactive analysis model.

Keywords: character education, religious, textbook.

\section{PENDAHULUAN}

Bidang pendidikan memegang peranan yang sangat penting dalam pembangunan sosial budaya, ekonomi negara, dan sumber daya manusia. Kurikulum 2013 dikembangkan dengan mengintegrasikan pendidikan karakter ke dalam setiap mata pelajaran di sekolah, salah satunya mata pelajaran Bahasa Indonesia. Prinsip ini seharusnya dijabarkan dalam isi buku teks agar dapat dilaksanakan dalam proses kegiatan belajar mengajar. Pengajaran Bahasa Indonesia di SMP tidak dapat dipisahkan dari adanya buku pelajaran Bahasa dan Sastra Indonesia yang memenuhi syarat akademik. Seperti yang dikatakan Tarigan (1986: 13), buku teks berperan penting untuk menunjang suatu program pengajaran.

Kurikulum 2013 memfokuskan pendidikannya pada tiga ranah yaitu sikap, keterampilan, dan pengetahuan. Dengan ini, kurikulum 2013 menuntut peserta didik untuk mengembangkan sikap/moral diri. Dengan melihat dan menelaah kondisi pendidikan saat ini, rendahnya karakter atau pembentukan sikap peserta didik menjadi fokus dalam kurikulum 2013. Konsep kurikulum 2013 merupakan wadah pembentuk karakter peserta didik baik secara religius maupun sosial. Adapun harapan nilai karakter yang ideal sesuai dengan sistem pendidikan nasional kurikulum 2013 yang ditetapkan oleh Kementrian Pendidikan Nasional yaitu religius, jujur, toleransi, disiplin, kerja keras, kreatif, mandiri, demokratis, rasa ingin tahu, semangat kebangsaan, cinta tanah air, menghargai prestasi, bersahabat, cinta damai, gemar membaca, peduli lingkungan, peduli sosial, dan tanggung jawab. Gagasan tentang nilai-nilai pendidikan karakter tersebut terbatas pada sekolah formal saja.

Dengan buku teks, peserta didik dapat mempelajari materi yang akan atau sudah disampaikan pendidik kapan pun. Efendi (2009: 3) mengatakan bahwa buku teks adalah buku yang dapat dijadikan sebagai pegangan peserta didik sebagai media pembelajaran (instruksional). Departemen Pendidikan Nasional (2006: 12) memaparkan komponen-komponen dalam buku teks, 
yaitu (1) pendahuluan berupa tujuan instruksional dan sebagainya; (2) uraian berupa penggunaan istilah/konsep, ciri-ciri, klasifikasi, rincian, rumus, contoh, penilaian, dan manfaat; (3) bentuk visual berupa tabel, format, bagan, peta, potret, dan gambar; (4) petunjuk praktik; (5) latihan, pertanyaan, dan tugas; serta (6) rangkuman.

Buku teks disusun oleh pakar. Dalam penyusunan buku teks Bahasa Indonesia, harus memperhatikan landasan penyusunan buku teks. Menurut Departemen Pendidikan Nasional (2006: 6-12) buku teks Bahasa Indonesia harus disusun dengan berlandaskan keilmuan bahasa dan sastra, ilmu pendidikan dan keguruan, serta keterbacaan materi dan bahasa yang digunakan. Lebih lanjut dijelaskan bahwa landasan keilmuan bahasa dan sastra Indonesia mengandung tujuh prinsip, yaitu (1) prinsip kebermaknaan, (2) prinsip keotentikan, (3) prinsip keterpaduan, (4) prinsip keberfungsian, (5) prinsip performansi komunikatif, (6) prinsip kebertautan (kontekstual), dan (7) prinsip penilaian.

Buku teks Bahasa Indonesia kelas VII jenjang SMP/MTs edisi revisi 2017 mencantumkan beberapa contoh teks yang erat kaitannya dengan pendidikan karakter. Salah satunya terdapat pada Bab II pada teks cerita fantasi bahwa Tuhan sudah menganugerahkan kemampuan berfantasi sebagai sumber kreativitas dan mengajak para peserta didik untuk memanfaatkannya.

Penelitian tentang pendidikan karakter pernah dilakukan oleh Agus, et al (2019) dengan judul "Cultural-Based Education of Tamanpeserta didik as a Locomotive of Indonesian Education System" yang menghasilkan pemikiran bahwa ajaran Ki Hadjar Dewantara berakar pada budaya luhur yang tidak hanya terfokus pada kecerdasan otak semata, tetapi juga membangun karakter yang baik berdasarkan konsep Trisakti Jiwa yang terdiri atas cipta, rasa, dan karsa. Kesinergisan antara ketiga konsep tersebut akan menghasilkan penalaran yang berkualitas, baik dari aspek emosional maupun motivasi. Selain itu, Agus et al (2019) juga berpendapat bahwa dalam sistem pengajaran dan pendidikan, diperlukan penerapan konsep Trilogi Kepemimpinan. Pernyataan tersebut menjelaskan bahwa dalam proses pengajaran dan pendidikan yang asah, asib, dan asuh, sangat diperlukan konsep Trilogi Kepemimpinan, yakni Ing Ngarsa Sung Tuladha, Ing Madya Mangun Karsa, dan Tut Wuri Handayani. Dengan penerapan konsep tersebut, maka pendidik memosisikan dirinya di depan sebagai model (teladan), di tengah untuk memberikan semangat, dan di belakang untuk memberikan dukungan dan dorongan. Hal ini disebabkan karena sistem pendidikan di Indonesa harus ditata secara cerdas, mendalam, kreatif, inovatif, terintegrasi, komprehensif, dan futuristik, tetapi tetap berpondasi pada nilai budaya luhur di Indonesia.

Penanaman pendidikan karakter dalam buku teks bahasa Indonesia dapat tecermin dalam materi, teks wacana, instruksi, dan soal. Kementerian Pendidikan Nasional (2010: 21) menjelaskan bahwa cara mengintegrasikan nilai-nilai karakter ke dalam materi pembelajaran dapat dilakukan dengan mengungkapkan nilai-nilai yang ada dalam materi pembelajaran, mengintegrasikan nilai-nilai karakter menjadi bagian terpadu dari materi 
pembelajaran, menggunakan perumpamaan dan membuat perbandingan dengan kejadian-kejadian serupa dalam hidup para peserta didik, mengubah hal-hal negatif menjadi nilai positif, mengungkapkan nilai-nilai melalui diskusi dan curah pendapat, menggunakan cerita untuk memunculkan nilai-nilai, menceritakan kisah hidup orang-orang besar, menggunakan lagu-lagu dan musik untuk mengintegrasikan nilai-nilai, menggunakan drama untuk melukiskan kejadian-kejadian yang berisi nilai-nilai, menggunakan berbagai kegiatan seperti kegiatan pelayanan, praktik lapangan melalui klub-klub atau kelompok kegiatan untuk memunculkan nilai-nilai kemanusiaan.

Sementara itu, dalam Lampiran Peraturan Menteri Pendidikan dan Kebudayaan Nomor 68 Tahun 2013 tentang Kerangka Dasar dan Struktur Kurikulum Sekolah Menengah Pertama/Madrasah Tsanawiyah pada Kompetensi Inti 1 (sikap spiritual) dan Kompetensi Inti 2 (sikap sosial), karakter yang harus dibangun meliputi religius, jujur, disiplin, tanggung jawab, peduli (toleransi, gotong royong), santun, dan percaya diri. Di samping pendidikan karakter menurut Kementerian Pendidikan Nasional dan yang terdapat pada KI 1 dan KI 2, Dewantara (2013) mengajarkan sikap-sikap karakter dalam fatwanya yang meliputi ngandel, kendel, bandel, dan kandel yang berarti percaya akan memberikan pendirian yang tegak kemudian diikuti dengan berani dan tidak lekas ketakutan.

Penelitian ini memfokuskan pada buku peserta didik mata pelajaran Bahasa Indonesia jenjang SMP. Hal ini dengan pertimbangan bahwa peserta didik SMP rentan dengan permasalahan pembentukan karakter. Sesuai perkembangan usia tersebut masih mencari jati diri dan mudah mendapatkan pengaruh dari luar terutama sikap negatif. Oleh karena itu, bentuk nilai-nilai harus tertuang dengan jelas dan mudah dipahami dan dilakukan oleh peserta didik, sedangkan dari sudut guru mudah untuk diteladankan (dicontohkan) secara nyata dalam kehidupan di sekolah. Berdasarkan latar belakang tersebut, maka peneliti mencoba untuk mendeskripsikan nilai religius yang terkandung di dalam buku teks Bahasa Indonesia jenjang SMP. Untuk itu peneliti mengambil penelitian dengan judul Nilai Religius dalam Buku Teks Bahasa Indonesia jenjang SMP. Atas dasar pertimbangan tersebut, penelitian ini dilakukan dengan harapa dapat menjadi masukan muatan nilai karakter untuk mempersiapkan buku ajar peserta didik.

\section{METODE}

Penelitian deskriptif merupakan salah satu jenis penelitian berdasarkan tingkat eksplanasi dengan mendeskripsikan hasil penelitian (Sugiyono, 2016: 7). Dengan demikian, penelitian ini termasuk penelitian deskriptif dengan metode kualitatif. Hal ini dikarenakan penelitian ini mendeskripsikan penerapan pendidikan karakter dalam buku teks peserta didik Bahasa Indonesia SMP. Data penelitian berupa frasa, kata, klausa, kalimat, paragraf, 
dan wacana yang memuat konten-konten tentang penerapan pendidikan karakter dalam buku teks Bahasa Indonesia SMP Kurikulum 2013. Menurut Arikunto (2010: 265), peneliti harus menyusun instrumen pengumpulan data dengan cermat supaya mendapatkan data yang tepat. Dalam hal ini, data dikumpulkan dengan teknik dokumentasi dengan instrumen penelitian berupa peneliti yang dibekali teori, dilengkapi dengan definisi operasional, dan kartu data yang memuat indikator aspek-aspek pendidikan karakter. Keabsahan data diawali dari validasi instrumen yang akan dilakukan oleh pakar atau expert judgment. Pakar atau expertjudgment dalam penelitian yang akan dipilih adalah ahli pengajaran bahasa berpendidikan minimal S-2. Pakar akan dibekali instrumen berupa kartu data dan definisi operasional. Adapun instrumen defenisi operasional terdapat pada lampiran. Selain itu, keabsahan data akan dilakukan dengan teknik pemeriksaan teman sejawat melalui diskusi atau Focus Group Discusion (FGD). Pada saat FGD, peneliti akan memaparkan dan mendiskusikan hasil penelitian sementara dengan ahli dan rekan sejawat (Rochmiyati, 2010: 74). Setelah data yang terkumpul dan diperiksa, kemudian data dianalisis. Analisis data pada penelitian kualitatif dapat dilakukan sejak awal sampai akhir penelitian (Sugiyono, 2016: 24). Pada saat proses pengumpulan data, proses analisis sudah dapat dimulai. Analisis data yang akan digunakan yakni model analisis interaktif. Model analisis interaktif terdiri atas tiga alur kegiatan yaitu reduksi data, penyajian data, dan penarikan kesimpulan/verifikasi (Milles dan Huberman, 2009: 16).

\section{Gambar 1.}

Komponen-Komponen Analisis Data Model Interaktif

(Miles \& Huberman, 2009: 16)

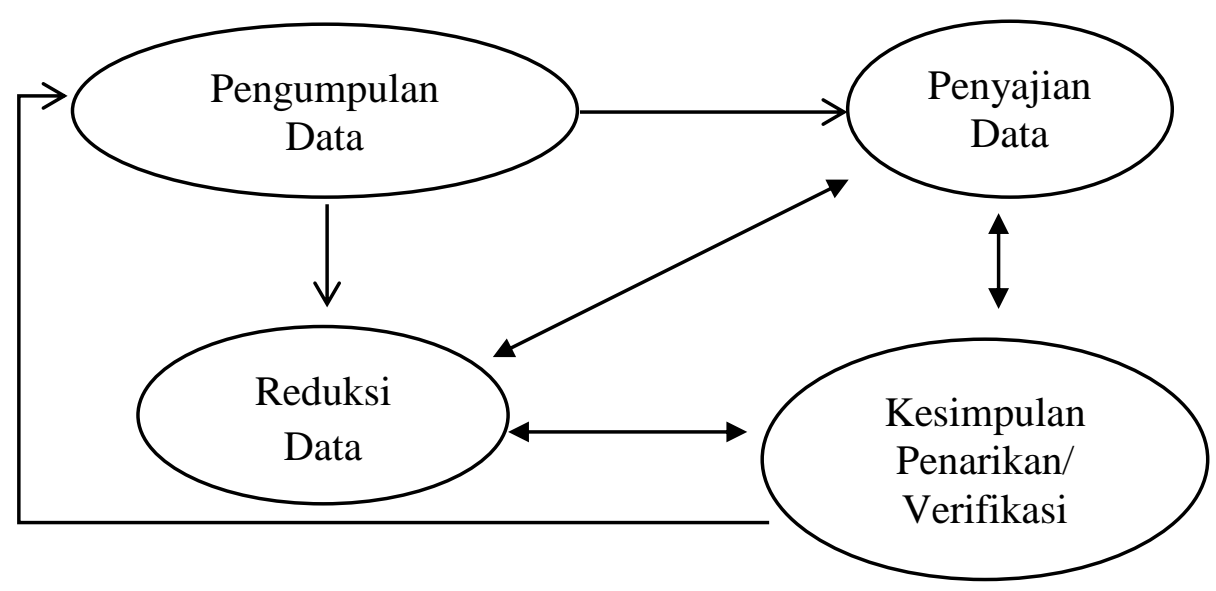

Nilai Religius dalam Buku Teks ... 
Lebih lanjut dijelaskan bahwa reduksi data merupakan proses pemilihan dan penyederhanaan dari catatan-catatan tertulis di lapangan. Data yang telah direduksi disajikan dalam bentuk teks naratif kemudian ditarik kesimpulan. Jika kesimpulan tidak didukung bukti-bukti yang valid, maka peneliti kembali ke proses alur awal.

\section{HASIL DAN PEMBAHASAN}

Berdasarkan pengamatan pada ketika buku teks pelajaran Bahasa Indonesia jenjang SMP Kurikulum 2013, ditemukan beberapa substansi wujud pendidikan karakter, di antaranya yakni wujud karakter manusia terhadap Tuhan, karakter manusia terhadap diri sendiri, karakter manusia terhadap sesama. Unsur pendidikan karakter yang terlihat intensif ada pada nilai karakter dalam hubungannya kepada Tuhan Yang Maha Esa. Dalam kaitannya dengan hal tersebut, maka nilai yang mendapatkan perhatian utama yakni nilai-nilai religius. Nilai religius merupakan nilai karakter yang memfokuskan pada bagaimana peserta didik dapat menghayati, meyakini, dan melaksanakan ajaran agama dan kepercayaan yang dianut.

Sikap merupakan kecenderungan yang relatif menetap yang beraksi dengan cara baik atau buruk terhadap orang atau barang tertentu (Syah, 2011). Sikap adalah suatu persiapan bertindak atau berbuat dalam suatu arah tertentu. Ada dua macam bentuk sikap yakni sikap individual dan sikap sosial. Sikap merupakan sebuah kecenderungan yang menetukan atau suatu kekuatan jiwa yang mendorong seseorang untuk bertingkah laku yang ditujukan ke arah suatu objek khusus dengan cara tertentu, baik objek itu berupa orang, organisasi, maupun masalah, bahkan jika itu mengenai dirinya sendiri. Sedangkan religius, terbentuk dari kata dasar 'religi' yang berasal dari bahasa asing religion sebagai kata bentuk dari kata benda yang berarti agama. Menurut Jalaluddin (2008), agama memiliki arti percaya kepada Tuhan atau kekuatan super buman atau kekuatan yang di atas dan disembah sebagai pencipta dan pemelihara alam semesta; ekspresi dari kepercayaan di atas berupa amal ibadah; dan suatu keadaan jiwa atau cara hidup yang mencerminkan kecintaan atau kepercayaan terhadap Tuhan, kehendak, sikap, dan perilakunya sesuai dengan aturan Tuhan seperti tampak dalam kehidupan kebiasaan.

Dari uraian di atas dapat disimpulkan bahwa sikap religius merupakan suatu keadaan diri seseorang yang jika melakukan setiap aktivitasnya selalu berkaitan dengan agamanya. Dalam hal ini pula dirinya selalu menghamba dan memercayai Tuhannya serta berusaha agar dapat merealisasikan atau mempraktikkan setiap ajaran agamanya atas dasar iman yang ada dalam batinnya.

Indikator pada aspek religius meliputi (a) berpegang teguh pada ajaran agama dan percaya kepada Tuhan (ngande), (b) melaksanakan ajaran agama dan kepercayaan yang dianutnya. Terdapat 31 data mengenai muatan 
pendidikan karakter nilai religius dalam buku peserta didik Bahasa Indonesia jenjang SMP kurikulum 2013, dengan rincian 10 data pada buku teks peserta didik kelas VII, 13 data pada buku teks peserta didik kelas VIII, dan 8 data pada buku teks peserta didik kelas IX. Berikut beberapa contoh muatan pendidikan karakter religius dalam buku teks peserta didik Bahasa Indonesia SMP Kurikulum 2013.

1. Berpegang teguh pada ajaran agama dan percaya kepada Tuhan (ngandel)

(1) Tuhan telah menganugerahkan kemampuan berfantasi sebagai sumber kreativitas. Ayo kamu manfaatkan! Kalau tekun berlatih pasti bisa. Gurumu akan memfasilitasi kamu untuk mengasah kreativitas dan menjadi penulis hebat! (Halaman 45, Bab II, Buku Peserta didik Kelas VII)

Dari penggalan data (1) tersebut, kementerian pendidikan berusaha untuk menanamkan kepercayaan pada peserta didik bahwa kemampuan berfantasi dan berkreasi tersebut merupakan anugrerah yang diberikan Tuhan kepada peserta didik.

(2) Pelajaran yang dapat kita ambil dari cerita itu adalah mulut kita dilarang berbicara yang menyinggung kekurangan orang lain. Tuhan menciptakan makhluknya dengan keistimewaan sendirisendiri. (Halaman 218, Bab VI, Buku Peserta didik Kelas VII)

Sama halnya dengan penggalan data (1), data (2) ini juga mencerminkan ajaran kepercayaan pada Tuhan dalam pembelajaran tersebut. Hal ini terlihat adanya pernyataan bahwa Tuhan telah menciptakan semua makhluknya (dalam hal ini peserta didik) dengan memiliki keistimewaan masing-masing.

(3) Sorga ada di telapak kaki ibu. (Halaman 33, Bab II, Buku Peserta didik Kelas VIII)

Penggalan data tersebut menjelaskan bahwa letak surga di dunia ini yaitu terdapat di "telapak kaki ibu". Maksud dari pernyataan itu yaitu dengan restu seorang ibu, maka seseorang juga akan diridai Tuhan. Sikap istikamah tersebut dimunculkan untuk menambah kepercayaan peserta didik kepada Tuhan dan berpegang teguh terhadap ajaran agamanya.

(4) Semua manusia pada dasarnya sama. Yang membedakan manusia di mata Tuhan bukanlah fisiknya, tetapi keimanan, kejujuran, kemuliaan, kebaikan dengan manusia lain. (Halaman 157, Bab VI, Buku Peserta didik Kelas IX)

Dari pernyataan pada penggalan data (4) di atas, penulis buku teks peserta didik Bahasa Indonesia terlihat berusaha untuk mengajarkan kepada peserta didik mengenai keimanan, kejujuran, kemuliaan, dan kebaikan dengan manusia lain. Dengan penanaman 
konsep tentang keimanan dan kemuliaan tersebut, diharapkan peserta didik semakin memegang teguh ajaran-ajaran dalam agama yang dipercayainya.

2. Melaksanakan ajaran agama dan kepercayaan yang dianutnya

(5) Pada unit ini kamu akan belajar tentang puisi rakyat. Kita patut bersyukur kepada Tuhan karena dianugerahi leluhur yang memiliki kearifan dan diwariskan melalui berbagai puisi rakyat. Kita juga patut terus bersyukur karena Tuhan memberikan cipta dan karsa untuk mencipta. (Halaman 166, Bab V, Buku Peserta didik Kelas VII)

Dari penggalan data tersebut, tim penulis mengajak para peserta didik untuk selalu bersyukur atas segala pemberian yang telah Tuhan anugerahkan. Pengungkapan rasa syukur ini diwujudkan dengan menciptakan suatu karya berdasarkan materi yang telah diajarkan. Selain ditujukan untuk menciptakan suatu karya, pengungkapan rasa syukur juga diungkapkan dalam fabel yang berjudul "Sesama Saudara Harus Berbagi" seperti pada penggalan data (6) berikut ini.

(6) "Kalian harus mau berbagi ya, anak-anak. Walau menurut kalian kurang, ini adalah rezeki yang harus disyukuri," lanjut Ibu Pip. (Halaman 198, Bab VI, Buku Peserta didik Kelas VII)

Rasa syukur ini secara eksplisit dicontohkan dalam suatu teks fabel agar peserta didik diharapkan dapat meneladani dan mengikuti cerita tersebut untuk selalu bersyukur atas rezeki yang dimiliki. Rasa syukur kepada Tuhan inilah salah satu bentuk melaksanakan ajaran agama yang dianutnya.

(7) Tiada lagi nasihat-nasihat yang indah itu. Kami semua kangen Ibu. Kerinduan kami hanya bisa diungkapkan lewat doa untuk Bu guru luar biasa seperti Ibu. Semoga ibu senantiasa sehat dan dalam lindungan-Nya. (Halaman 247, Bab VII, Buku Peserta didik Kelas VII)

Perwujudan pelaksanaan ajaran agama juga digambarkan dalam bentuk doa-doa untuk Bu Guru kepada Tuhan yang disampaikan oleh seorang peserta didik di dalam surat. Penggambaran mengenai ajaran berdoa kepada Tuhan ini juga terdapat dalam buku peserta didik kelas VIII seperti pada penggalan data (8) berikut ini.

(8) Dengan kata-kata itu, penyair bermaksud menggambarkan keadaan dirinya ketika sedang berdoa kepada Allah, Tuhan Yang Mahakuasa. Ia menggambarkan dirinya lemah. Namun, ia pun merasakan suasana tenteram. Melalui kata-kata itu pula 
penyair menunjukkan keinginan agar Tuhan mengisi seluruh kalbunya. Tentang besarnya cinta, kerinduan, dan kepasrahan sang penyair akan Tuhannya. (Halaman 100, Bab IV, Buku Peserta didik Kelas VIII)

Dari penggalan data di atas, penulis buku secara implisit berusaha membiasakan peserta didik untuk berdoa kepada Tuhan melalui kata-kata penyair dalam puisinya. Melalui penjelasan tentang puisi tersebut, penulis mengajarkan peserta didik untuk membiasakan berdoa kepada Tuhan dan bertawakal melalui berbagai media, salah satunya media puisi.

(9) ... Berdoalah sebelum belajar dengan niat tulus akan belajar sungguh-sungguh... (Halaman 194, Bab VII, Buku Peserta didik Kelas VIII)

Penggalan data (9) di atas menunjukkan usaha untuk mengajak peserta didik berdoa terlebih dahulu sebelum belajar. Dengan berdoa terlebih dahulu, maka peserta didik akan selalu mengingat Tuhan dan melaksanakan ajarannya untuk selalu berdoa sebelum melakukan segala aktivitas.

(10) Pada teks cerita pendek berjudul "Pohon Keramat" Halaman 5360, berikut kutipannya:

Bagi saya, Gunung Beser menyimpan kenangan tersendiri. Sejak umur 5 tahun saya sering tidur di rumah Kakek. Setiap subuh Kakek membangunkan saya dan mengajak pergi ke masjid kecil di pinggir sawah. Saya yang kadang masih merasa ngantuk, begitu turun dari rumah selalu takjub melihat Gunung Beser berdiri kukuh. Saya merasa kesegaran pagi-harum dedaunan dan bau tanah_-adalah bau khas Gunung Beser. Saya selalu berharap begitu turun dari rumah bisa melihat gunung itu bercahaya.

Selesai salat, Kakek biasa mengontrol air sawah. Saya selalu menguntitnya dari belakang tanpa banyak bicara.

Dari pematang yang lebar-lebar, saya menyaksikan bagaimana Gunung Beser yang seperti patung raksasa hitam itu lambat laun bercahaya tertimpa sinar matahari. Saya sering beranggapan bahwa cahaya itu bukan dari matahari, tetapi keluar dari hati saya sendiri. Setiap melihat dedaunan yang bergoyangan, saya sering melamun melihat Mbah Jayasakti salat di atas daun pisang.

Setiap sore, kecuali hari Jumat, anak-anak belajar mengaji di masjid. Kakek awalnya mengajar, tapi akhirnya diteruskan oleh Kang Hasim. Saya menjadi anak emas apabila Kang Hasim mengajar. Selain dari Kang Hasim, saya belajar mengaji dari 
Kakek, bagi saya mengaji bukan hal baru. (Halaman 54-55, Bab III, Buku Peserta didik Kelas IX)

Berdasarkan penggalan data (10) tersebut, terlihat banyak sekali nilai-nilai religius mengenai pelaksanaan ajaran agama dan kepercayaan yang dianutnya. Pemuatan nilai-nilai tersebut terlihat dari apa yang dilakukan tokoh "Kakek". Apa yang dilakukan "Kakek" tersebut, seperti ketawaduannya, keistikamahannya, dan usaha atau keikhtiaran seorang kakek tersebut seolah ingin mengajarkan dan mendidik peserta didik untuk melakukan ajaranajaran seperti yang dilakukan oleh tokoh "Kakek".

Berdasarkan data yang telah ditemukan berkaitan pada aspek yang pertama, 'berpegang teguh pada ajaran agama dan percaya kepada Tuhan (ngandel)', nilai-nilai religius yang tergambar dalam materi buku teks tersebut dapat membantu membentuk karakter peserta didik menjadi lebih berakhlak mulia. Nilai-nilai religius yang tergambar mencerminkan akhlak yang baik bagi seseorang yaitu akhlak kepada Allah Swt., akhlak kepada orang tua, dan akhlak dalam menerima ketentuan Allah. Selain berpegang teguh pada ajaran agama dan percaya kepada Tuhan (ngandel), ada aspek kedua yang menjadi indikator penelitian, yakni 'melaksanakan ajaran agama dan kepercayaan yang dianutnya'.

Dari aspek kedua tersebut, nilai religius dari materi pembahasan diharapkan dapat dilaksanakan oleh peserta didik dalam kehidupan seharihari. Data yang tergambar sebagai bentuk pemuatan nilai religius sudah memunculkan nilai yang mengarah ke acuan indikator dalam penelitian. Oleh karena itu, materi di dalam buku teks Bahasa Indonesia jenjang SMP dapat berguna untuk peserta didik dalam membentuk kepribadian yang religius sesuai dengan tujuan yang tertuang di dalam kurikulum 2013 yaitu menjadikan manusia yang beriman, berakhlak, dan bertakwa kepada Tuhan Yang Maha Esa. Hal ini merupakan sikap yang berguna bagi seorang peserta didik yang merupakan pelajar yang baru berusia remaja. Dengan cerpen-cerpen yang digunakan sebagai materi pembelajaran sastra tersebut dapat menumbuhkan sikap-sikap yang lebih religius lagi baik itu berguna bagi diri sendiri maupun orang-orang yang berada di sekitarnya.

\section{KESIMPULAN}

Berdasarkan hasil penelitian yang telah penulis lakukan dalam buku teks Bahasa Indonesia jenjang SMP Kurikulum 2013, dapat disimpulkan bahwa nilai religius dalam materi pembelajaran pada buku teks bahasa Indonesia SMP/MTs adalah sebagai berikut. Nilai religius dalam materi pembelajaran 
pada buku teks bahasa Indonesia SMP/MTs tergambarkan melalui penguraian karya sastra, misalnya syair dan puisi, tokoh-tokoh dalam cerita, serta kalimat petunjuk untuk melakukan/mengerjakan sesuatu. Nilai religius seperti nilai syukur, ikhtiar, tawakal, tawadhu, dan istikamah dapat dipelajari dari beberapa penggalan dalam materi pembelajaran tersebut. Nilai religius syukur tergambar dalam materi tentang Cerita Fantasi pada kelas VII; nilai religius istikamah dalam materi Iklan, Sarana Komunikasi pada kelas VIII; tawadu dalam materi Cerita Pendek pada kelas IX, tawakal dalam materi Indahnya Berpuisi pada kelas VIII; ikhtiar dan istikamah dalam materi Cerita Pendek pada kelas IX. Nilai religius tersebut mencerminkan akhlak sesorang yaitu akhlak kepada Allah Swt., akhlak kepada orang tua, dan akhlak dalam menerima ketentuan Allah. Hal ini baik untuk peserta didik teladani dan terapkan dalam pembelajaran di sekolah maupun kehidupan sehari-hari.

\section{DAFTAR PUSTAKA}

Agus, Cahyono, et al. 2019. "Cultural-Based Education of Tamansiswa as a Locomotive of Indonesian Education System". Springer Nature Switzerland. Universities as Living Labs for Sustainable Development. World Sustainability Series. Springer, Cham.

Arikunto, S. 2010. Prosedur Penelitian Suatu Pendekatan Praktik. Jakarta: Rineka Cipta.

Dewantara, Ki Hadjar. 2013. Bagian Pertama: Pendidikan Pemikiran, Konsepsi, Keteladanan, Sikap Merdeka). Yogyakarta: UST Press bekerja sama dengan Majelis Luhur Persatuan Tamansiswa.

Harsiati, Titik, Agus Trianto, dan E. Kosasih. 2017. Bahasa Indonesia Edisi Revisi SMP/MTs Kelas VII. Jakarta: Kemendikbud.

Kementrian Pendidikan Nasional. 2010. Buku Pedoman Pendidikan Karakter di Sekolah Menengah Pertama. Jakarta: Direktorat Jenderal Mandikdasmen, Direktorat Pembinaan SMP.

Kosasih. 2017. Bahasa Indonesia SMP/MTs Kelas VIII Edisi Revisi 2017. Jakarta: Kemendikbud.

Miles, Matthew B. \& A. Michael Huberman. 2009. Analisis Data Kualitatif. Jakarta: UI-Press.

Sugiyono. 2016. Metode Penelitian Kombinasi (Mixed Methods). Bandung: Penerbit Alfabeta.

Syah, Muhibbin. 2011. Psikologi Pendidikan. Bandung :PT Remaja Rosdakarya. Tarigan. 1986. Telaah Buku Teks Bahasa Indonesia. Bandung: Aksara.

Trianto, Agus, Titik Harsiati, dan E. Kosasih. 2018. Bahasa Indonesia SMP/MTs Kelas IX Edisi Revisi 2018. Jakarta: Kemendikbud. 